\title{
Facebook Messenger as an Educational Platform to Scaffold Deaf Students' Conceptual Understanding in Environmental Science Subject: A Single Group Quasi-Experimental Study
}

\author{
Jayson A. Dela Fuente \\ Northern Negros State College of Science and Technology, Philippines
}

delafuentejayson89@gmail.com

First draft received: 17 Jan 2021 Date Accepted: 31 March $2021 \quad$ Final proof received: 28 Apr 2021

\begin{tabular}{l} 
Abstract \\
The advent of technology proliferates the evolution of social media that creates a massive breakthrough in \\
different aspects of life, especially in education. Teachers play a crucial role as they adapt to the new era of \\
an educational system where students with special needs are mainstreamed in the regular learning \\
environment. Student's success in learning is attributed to teachers' effective techniques, methods, and \\
approaches to deliver quality and meaningful learning to diverse students regardless of religion, ethnic \\
groups, race, culture, and disabilities. This context inspired the author to investigate the effectiveness of \\
Facebook Messenger as an educational platform in teaching to scaffold deaf students' conceptual \\
understanding in environmental science subject through a quasi-experiment to a single group composed of \\
four (N=4) deaf college students in one selected State College of the Higher Education Institutions (HEls) in \\
Northern Negros Philippines. The findings revealed that deaf students had a very low conceptual \\
understanding of the subject in the pre-test, however, manifested very high after the intervention (post-test). \\
Moreover, results show that there was no significant difference in the level of the participants' conceptual \\
understanding between and among gender groups, however, the difference was significant in the pre-test \\
and post-test gained scores. Furthermore, Facebook Messenger has been proven effective and thereby \\
recommended to maximize its potential as an educational tool in teaching to scaffold deaf students' \\
conceptual understanding of science fields and other disciplines. \\
Keywords: conceptual understanding; deaf students; educational platform; environmental science, \\
Facebook Messenger \\
\hline \hline \\
To cite this paper (in APA style): \\
Dela Fuente, J. A. (2021). Facebook Messenger as an educational platform to scaffold deaf students' \\
conceptual understanding in environmental science subject: A single group quasi-experimental study. \\
International Journal of Education, 14(1), 19-29. doi: 10.17509/ije.v14i1.31386 \\
\hline
\end{tabular}

\section{INTRODUCTION}

Teachers are the prime agent in shaping and molding students' knowledge, skills, and values to foster holistic development towards a successful life. The ultimate goal of every teacher and academic institution is to become responsive to the new paradigm of education, that is inclusive education. To emulate the demands on the global standards for inclusive education, teachers should be flexible, creative, and innovative to deliver quality and meaningful learning experiences not only to normal students but also to students with special needs in the mainstream learning environment (Dela Fuente, 2021).

The World Federation of the Deaf (WFD) advocates and promotes the rights of the deaf to access quality inclusive education with direct instruction through sign language from the teachers and the normal students or peers to foster their social and moral facets. Its main goal is to enforce inclusive educational reforms and agendas in different countries across the globe. Accordingly, the United Nations International Children's Emergency Fund (UNICEF, 2013) reported that most children with disabilities faced discrimination on their rights to have equal access to quality education. Yu et al. (2011) in particular emphasized that there is a great number of students with disabilities who are still denied access to education. Whilst the Western counterparts' struggle to mainstream students with special needs in the regular classroom (Ellsworth \& Zhang, 2007). The phenomenon provides a clear picture that supports the school as an essential element to the education of students with special needs in an inclusive learning environment (Slee, 2018; Deloitte Access Economics, 2017). The World Report on Disability cited several countries in Africa, Asia, and South America where students with special needs are 
deprived of opportunities to acquire education (WHO, 2011). Global data for the absence of students with special needs in the mainstream school has been dramatically evident in Uganda (Atekyereza, 2001), South Africa (Ward \& Seager, 2010), Zimbabwe (Chakuchichi et al., 2015); and Kenya (The World Bank, 2008). These global occurrences are also prevalent in Bangladesh, Burkina Faso, Cambodia, Costa Rica, Dominican Republic, Ethiopia, Ghana, Indonesia, Liberia, Mali, Malawi, Mexico, Mozambique, Peru, South Sudan, Vietnam and Zambia (Male \& Wodon, 2017).

Worldwide, almost 124 million students with special needs are not enrolled either in primary or secondary education (Singal, 2016) and even withdraw or leave from schooling before completing their education as cited by the UNESCO Institute Statistics (UIS, 2017). Similarly, the World Health Organization (WHO) observed that students with special needs in developed countries experienced worse educational outcomes than the normal students without disabilities (OECD, 2012; Barnes \& Sheldon, 2010). The situation even worsens in developing countries (Muderedzi \& Ingstad, 2011; WHO, 2011). Apparently, the separation of students with special needs into the mainstream school or in inclusive education with the normal students is still evident. This happens despite several research findings that support positive learning outcomes for students with special needs in an inclusive/regular learning environment (Myers et al., 2016). This was strengthened by Cologon (2013) that students with special needs who are in the mainstream school or the regular classroom performed better than those who attend separate special schools. The aforementioned phenomenon is evident in England (Tomlinson, 2017), Canada (Porter \& Towell, 2013), and Italy (D' Alessio, 2011).

In developing countries like the Philippines, the number of students with special needs was observed to be increasing especially in tertiary/college higher education. The National Council on Disability Affairs (NCDA) pointed out that there are still instances where students with special needs don't have the opportunity to go to college or not being admitted to colleges and universities mainly due to lack of awareness and preparation of the school administrators and teachers (NCDA, 2013). This is very evident in the international arena, in which barely $2 \%$ of 400 million students with disabilities across the globe have a chance to acquire higher education which simply implies the fewer students with special needs are catered their rights to access quality education. Based on the Philippines Statistics Authority (PSA) census among 4,446,649 million surveyed by the Department of Social Welfare and Development (DSWD) in the Pantawid Pamilyang Pilipino Program known as (4P's) 302,421 or about $6.77 \%$ are Persons with Disabilities (PWD) and 27,972 or about $0.63 \%$ are deaf, $97 \%$ of which does not reach the public school system despite zero rejection policy (PSA, 2010). In the later census of the National Statistics Office (NSO) in 2000 among 942,098 PWDs,
$13.91 \%$ are deaf which $4.13 \%$ hold an academic degree, however, the figures manifest the lesser number who finished/graduated from the college level. It was estimated that among 45,000 who have disabilities, $15 \%$ of them are to be enrolled in school. However, data gathered from the civil society revealed that the actual estimated enrollment of students with disabilities is less than $10 \%$, and even lower for deaf students.

The cited works of literature inspired the Commission on Higher Education (CHED) to respond and address certain concerns related to students with special needs which is anchored on the provisions of the United Nations (UN) Convention on the Rights of Persons with Disabilities (CRPD) through CHED Memorandum Order (CMO) 23 of 2000 [Quality Education for Learners with Special Needs] that urges Higher Education Institutions (HEls) to consider the following provision to cater the inclusive higher learning environment for quality education to students with special needs: 1) admit students with special needs, 2) inclusion of SPED programs for teacher training institutions, and 3) facilities and equipment be modified to ensure its accessibility to students with special needs. On October 30, 2018, the Filipino deaf community rejoices with the pronouncement of the approved Republic Act 11106 by President Rodrigo Roa Duterte of the Republic of the Philippines [An Act declaring the Filipino Sign Language as the national sign language of the Filipino deaf and the official sign language of government in all transactions involving the deaf, and mandating its use in schools, broadcast media, and workplaces] that mandates the Department of Education (DepEd), Commission on Higher Education (CHED), and the Technical Education and Skills Development Authority (TESDA) the academic agencies involve in educating deaf students to coordinate with each other on the use of Filipino Sign Language as the medium of instruction in deaf education. However, teachers in the State College of the Higher Education Institution (HEI) where the study was conducted do not have the skills in sign language.

Students with special needs access to quality education in mainstream school remains a challenge among academic institutions worldwide. The perspective enthused teachers to embrace the advantage of technological platforms that include social networking sites as a teaching tool to scaffolds students learning (Dabbagh \& Kitsantas, 2012). There are several social networking sites adopted by teachers in teaching diverse students such as Instagram, Twitter, Skype, Viber, and Facebook (Greenhow \& Askari, 2017). Through these platforms, the teachers, the normal students, and the deaf students have an opportunity to connect, communicate, and interact with each other in the virtual world for educational purposes (Antoniadis et al., 2017). The different platforms have a vital role to play in deaf students' knowledge acquisition since they have a challenge in conventional face-toface teaching for they have difficulty hearing sounds 
whilst the teacher's primary mode of instruction is through verbal communication (Raike, 2011).

Facebook is considered to be a model environment for communication and interaction that facilitates language learning and teaching (Aydin, 2012). When Facebook launched its chat application through Facebook Messenger App, interestingly it garnered almost 1.2 billion active users in 2017 adding 200 million users in a matter of eight months (Constine, 2017). Chowdry (2017) believes that the popularity of Facebook is certainly knotted to its desire to incorporate features to other social networking sites into its design like the Messenger App. Facebook Messenger enables users to send text messages, make voice, video calls, and send files through this app. Similarly, users can also create groups that allow them to communicate and interact with different people across the globe in the virtual world (Constine et al., 2016). Statista (2018) implied that the Philippines had a total of almost 47 million users which hailed the country as the number one largest Facebook arcade in Southeast Asia. In which according to Vrettaros et al. (2010) students are the fastest in the adaption of Facebook features and unique uses. There are several studies conducted as to the effect of social media on different aspects of the normal student's life, however, there is a dearth researches and works of literature in the Asia Pacific region (Alborz et al., 2013) on students with special needs like the deaf; and in the Philippines the author claims. Limited studies were noted on the use of social media like Facebook on deaf students learning (Saunders 2016). Moreover, there are only a few types of researches on the effect of social media on learning, however, it focused mainly on the self-reported questionnaire that provides a mere perception of the phenomenon.

Notably, Facebook continues to evolve as it offers a new unique feature: The Messenger App which forefront teachers to become creative and innovative as to its significant value as a tool or aid in teaching deaf students. The dearth studies and works of literature on the effect of social media as to its advantage to deaf students learning inspired the author to conduct an investigative study through a single group quasiexperiment. Based on the gathered works of literature through different data-based sources of researches like GoogleScholar, Researchgate, Mendeley, Academia, and even in the open-access selected local and international journals, it was noted that the author piloted the study in the Philippines, in the Asia Pacific region and across the globe which is very specific to the context of Facebook Messenger utilized by the author/teacher as an educational platform in teaching to scaffold the conceptual understanding of deaf college students towards the Environmental Science subject. The findings will shed light on the importance of technology with the essential discovery of social media in the teaching-learning process in an inclusive education learning environment that can contribute to the literature worldwide.

\section{Objectives of the Study}

The study aimed to investigate the effectiveness of Facebook Messenger as an educational platform to scaffold deaf students' conceptual understanding of Environmental Science subject. Specifically, it attempted to answer the following statements:

1. Determine the level of deaf students' conceptual understanding in Environmental Science subject according to gender and exposure to Facebook.

2. Compare the level of difference of deaf students' conceptual understanding in Environmental Science subject according to pre-test and posttest between gender groups and among gender.

3. Compare the level of difference of deaf students' conceptual understanding in Environmental Science subject on the pre-test and post-test to determine the effectiveness of Facebook Messenger as an educational platform in teaching to scaffold deaf students' conceptual understanding.

\section{Null Hypotheses}

Based on the stated objectives, the following hypotheses were proposed.

$H_{0}$ 1. There is no significant difference in the level of deaf students' conceptual understanding in Environmental Science subject in pre-test and post-test between gender groups.

$H_{0}$ 2. There is no significant difference in the level of deaf students' conceptual understanding in Environmental Science subject in pre-test and post-test among gender.

$H_{0}$ 3. There is no significant difference in the level of deaf students' conceptual understanding in Environmental Science subject in pre-test and posttest.

\section{METHODOLOGY}

\section{Research Design}

The study employed quasi-experimental research specifically a single group pre-test-post-test experimental design. In this approach, a single group exclusively the four unanticipated deaf college students enrolled in the institution are pre-tested and was given a treatment, then post-tested (Salkind, 2010) to determine any significant difference in the variables before and after exposure to Facebook Messenger as an educational platform in teaching to scaffold deaf students' conceptual understanding in Environmental Science subject.

\section{Participants}

The participants were four (4) unanticipated deaf college students taking Bachelor of Science in Hospitality Management (BSHM) enrolled officially for the Second Semester of the Academic Year 2018-2019 in one selected State College of the Higher Education Institutions (HEIs) in Northern Negros Philippines. Two of whom are males and two are females which age range from 25 to 30 years old. The participants were chosen purposively since the author taught the subject Environmental Science subject to this group of students 
who are mainstreamed together with the thirty-nine (39) normal students in a regular classroom.

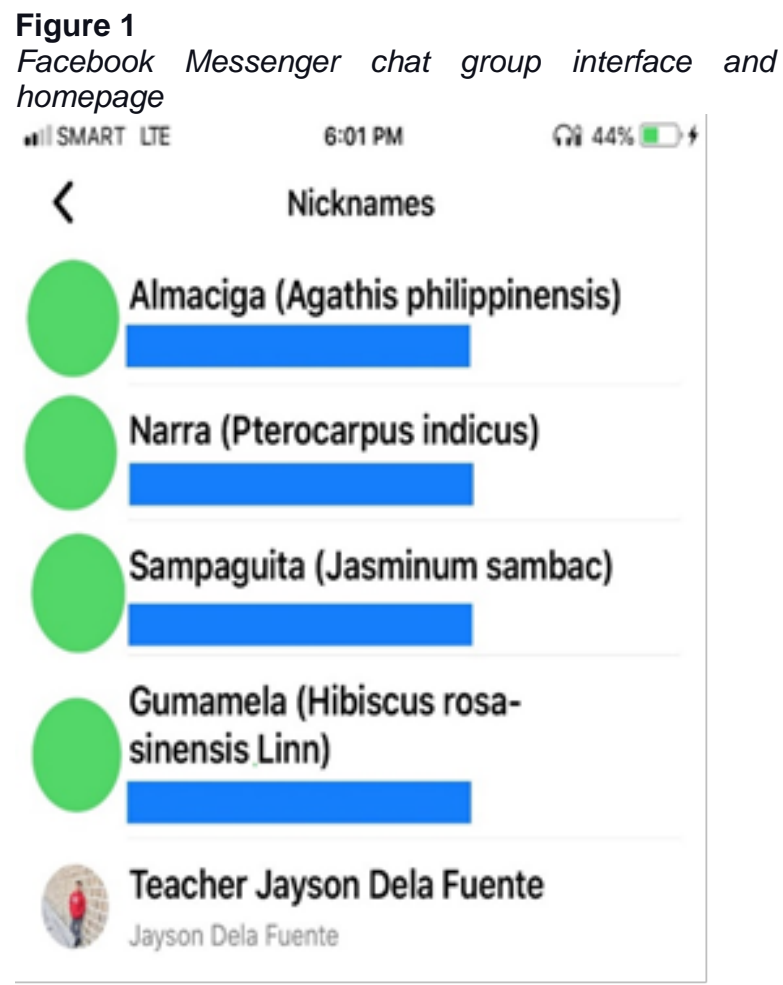

\section{Ethical Consideration}

The study was presented and approved by the institution's Research and Development Office through an In-House Research Review. Moreover, the author sought ethical approval and permission from deaf students before the conduct of the study with the purpose, and procedures were explained with the help of a student interpreter who is skilled in sign language to ensure accuracy and $100 \%$ retrieval of the needed statistical data. The participants signed a consent form to manifest their voluntary participation in the experiment, then, was given a code of the scientific name of trees (for males) and flowers (for females) to protect their identity and to assure the confidentiality of the information given especially on the transcript of class discussions and conversations in the Facebook Messenger chat group.

\section{Research Instrument}

To gather empirical evidence and data, the author prepared a Table of Specification (TOS) and developed a test/examination in Environmental Science subject anchored on the topics covered in each term examination Prelim (components of the ecosystem, biochemical cycles, food chain, food web, and ecological pyramid); for the midterm (population, the impact of population growth on the environment, and environmental issues and concern); and for the final (environmental pollution, approaches in solving environmental problems, and sustainable development) postulated in the author's/teacher's approved course syllabus. The test/examination was composed of a fifty (50) item multiple-choice with the given alternatives for students to choose from which was designed based on Bloom's Taxonomy of
Objectives on test construction that includes remembering, understanding, applying, analyzing, evaluating, and creating, further reflected in the TOS made by the author. The 50 items test/examination was administered before (pre-test) and after (post-test) of each term examination as scheduled: September 18 (Prelim), October 23 (Midterm), and December 4 (Final) of 2018.

\section{The validity of the Instrument}

The author utilized researcher-made test/examination questions as an instrument of the study. It went through a series of rigorous content and face validity of experts in test construction, instrumentation, and evaluation before it was administered to students in the scheduled examination. The instrument was validated by the Testing Coordinator who is considered an expert in the Do's and Don'ts in test construction; the Science Coordinator who rigorously examined the correctness and accuracy of the concepts/contents; the Dean who further evaluated the questions in the test if it is aligned with the course syllabus; and finally the Chairperson of the Curriculum Instruction Materials and Development (CIMD) who is an expert in the content and face validity of the test/examination constructed, then by the Vice President for Academic Affairs who signified that the examination was found to be valid and approved to administer to the students.

\section{Data Collection}

\section{Phase 1: Pre-Experimental}

The author/teacher created a Facebook Messenger chat group exclusively and purposively for deaf students with the homepage name "Environmental Science subject POLARIS Group 2nd Semester 20182019' with a profile picture of a Mangrove Forest taken in one Island situated near the school to match with the subject. To give an overview, POLARIS is commonly known as the Northern Star and the brightest star in the constellation of Ursa Minor of which the author/teacher referred to deaf students as the brightest among the stars in the classroom since they are a unique individual. Deaf students were then added in the Facebook Messenger chat group with the given Pseudonyms of the Philippines' pride trees (for male) and flowers (for female) with the corresponding scientific names as follows: Participant 1 Narra (Pterocarpus indicus), Participant 2 Almaciga (Agathis philippinensis), Participant 3 Sampaguita (Jasminum sambac) and for the Participant 4 Gumamela (Hibiscus rosa-sinensis Linn) to hide their identity and to protect confidentiality (see Figure 1).

\section{Phase 2: Experimental}

The author/teacher conducted the regular class in the time scheduled at 4:00-5:30 of the afternoon every Monday and Wednesday of which deaf students $(\mathrm{N}=4)$ are mainstreamed in the regular classroom with the normal students $(\mathrm{N}=39)$ using the conventional teaching approach for the whole course content for Prelim from October to November 2018; for the Midterm from December 2018 to January 2019; and for the Final from February to March 2019 that covered 6 months of teaching for the entire semester of the A.Y. 2018-2019 as reflected in the author/teacher course syllabus. In 
the conventional approach of teaching as observed by the author/teacher, deaf students have not participated since they have difficulty hearing what the author/teacher discuss in the class. To help deaf students understand the concepts in Environmental Science subject the author/teacher with permission from deaf students conducted a follow up online "remedial class" through Facebook Messenger as a scaffold for their conceptual understanding of the subject. Since the author/teacher and deaf students have scheduled class after the regular Environmental Science subject class, the experimental set-up was conducted every night following the same scheduled day (Monday and Wednesday) from 6:00-7:00 as agreed and permitted by deaf students (see Figure 2).

\section{Figure 2}

Sample transcripts of online class teaching
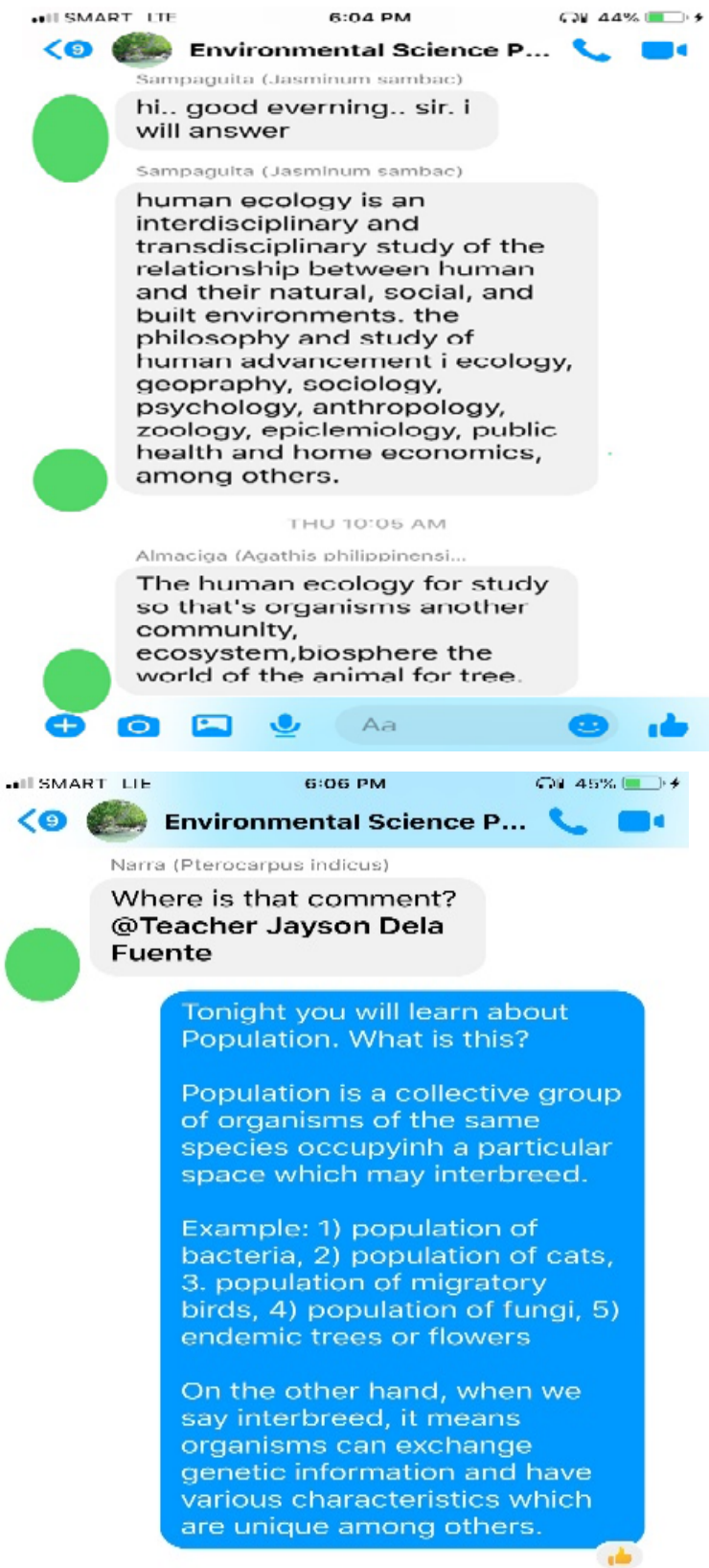

\section{Phase 3: Post-Experimental}

The author/teacher administered the 50 items MultipleChoice Environmental Science Test/Examination each term (Prelim, Midterm, Final) on scheduled dates by the Office of the Vice President for Academic Affairs after the conduct of remedial class through Facebook Messenger as a scaffold to deaf students' conceptual understanding in the different topics/lessons/course contents in respective terms Prelim (November 20, 2018), Midterm (February 14, 2019), and Final (March 18, 2019) after deaf students were exposed to Facebook Messenger as education platform in teaching to scaffold their conceptual understanding in Environmental Science subject that serve as the posttest. The results of the pre-test and post-test were assessed and analyzed with the aid of statistical data analysis to find out the effectiveness of Facebook Messenger as a scaffold to deaf students conceptual understanding in Environmental Science subject online class discussion.

\section{Statistical Analysis of the Data}

In the process of the obtained data through test items in the examination for prelim, midterm and final, the following descriptive inferential statistics were employed: Mean, one-sample t-test, and paired t-test to determine deaf students' conceptual understanding in Environmental Science subject through Facebook Messenger as an educational platform in teaching in scaffolding their conceptual undertaking towards the subject. All computation in the gathered empirical statistical data was done using the computer process Statistical Package for the Social Sciences (SPSS). The following mean score range and its equivalent verbal interpretation were used as a guide in the analysis and elucidation of the quantitative findings.

Table 1

Score range

Mean Score Range Verbal Interpretation

\begin{tabular}{cc}
\hline $40.20-50.00$ & Very High \\
\hline $30.40-39.19$ & High \\
\hline $19.60-29.39$ & Average \\
\hline $9.80-19.59$ & Low \\
\hline $1.00-9.79$ & Very Low \\
\hline
\end{tabular}

\section{RESULTS}

The deaf students' conceptual understanding of the subject was Very Low in the prelim and final while Low in the midterm as indicated in their mean scores which ranges from 8 to 10 over a total of 50 items/questions in the pre-assessment (pre-test) examination in each term (prelim, midterm, final). Results show that deaf students had a limited understanding of the different concepts of the subject matter. They expressed through sign language which was interpreted by their classmates (normal students) and relay to the author/teacher that they find the examination difficult since it's their first time to encounter such concepts and they don't have any idea about it. The author/teacher inferred that the notion of difficulty encountered by deaf students was due to their chosen track when they were in senior high school 
which is not aligned to the science field as such they were not able to expose themselves to science concepts specifically in the domain of Environmental Science subject (see Table 2).

\section{Table 2}

Deaf student's level of conceptual understanding in Environmental Science subject before (pre-test) and after (post-test) exposure to Facebook Messenger

\begin{tabular}{lllll}
\hline Variable & N=4 & Mean & SD & Interp. \\
\hline Prelim & Pre-test & 9.75 & 2.22 & $\begin{array}{l}\text { Very } \\
\text { Low }\end{array}$ \\
\hline & Post-test & 38.0 & 2.94 & High \\
\hline Midterm & Pre-test & 10.3 & 2.87 & Low \\
\hline Final & Post-test & 38.5 & 1.29 & High \\
\hline & Pre-test & 8.75 & 2.50 & $\begin{array}{l}\text { Very } \\
\text { Low }\end{array}$ \\
\hline & Post-test & 38.8 & 2.87 & High \\
\hline
\end{tabular}

Table 3

Deaf students' level of conceptual understanding in Environmental Science subject before (pre-test) and after (posttest) exposure to Facebook Messenger according to gender

\begin{tabular}{lllll}
\hline Variable & N=4 & Mean & SD & Interpretation \\
\hline Prelim & Male (Pre) & 9.50 & 3.54 & Very Low \\
\hline & Male (Post) & 37.5 & 4.95 & High \\
\hline & Female (Pre) & 10.0 & 1.41 & Low \\
\hline Midterm & Female (Post) & 38.5 & .707 & High \\
\hline & Male (Pre) & 11.0 & 4.24 & Low \\
\hline & Male (Post) & 38.5 & 2.12 & High \\
\hline & Female (Pre) & 9.50 & 2.12 & Very Low \\
\hline Final & Female (Post) & 38.5 & .707 & High \\
\hline & Male (Pre) & 9.00 & 4.24 & Very Low \\
\hline & Male (Post) & 38.5 & 4.95 & High \\
\hline & Female (Pre) & 8.50 & .707 & Very Low \\
\hline
\end{tabular}

Accordingly, when the deaf students were grouped as to gender data revealed that their level of conceptual understanding in Environmental Science subject was distinct, where males got the mean score of 9.50 interpreted as very low, while the female was at the low level $(m=10.0, S D=1.41)$ in the prelim. on the other hand, the female had $\mathrm{a}=9.50$ and $\mathrm{SD}=2.12$ that falls to the very low level while the male was at low level gained 11.0 correct scores in the standard deviation of 4.24 in the pre-assessment examination for the midterm. however, both male and female are at the very low level (Male: $M=9.00, S D=4.24$; Female: $M=8.50$, $\mathrm{SD}=.707$ ) when the final pre-test examination was administered. In general, the given data shows that both genders did not exhibit scientific competence in Environmental Science subject before the implementation of the intervention as they garnered low scores in the given pre-examination for prelim, midterm, and final.

Moreover, based on the post-test or after deaf students were exposed to Facebook Messenger as a tool used by the author/teacher in teaching their level of
Apparently, after the deaf students were exposed to Facebook Messenger as a teaching device it turned out that their scores in the term examination (post-test) escalates as it was demonstrated by the means of 38.0, 38.5, and 38.8 which were interpreted as High in the prelim, midterm, and final, respectively. The figures convey that the strategy of the author/teacher of utilizing Facebook Messenger enhances the conceptual understanding of deaf students in Environmental Science subject. Moreover, their increasing scores from prelim, midterm, and the final is visible which means that their level of understanding was developed through the aid of the intervening educational platform used by the author/teacher in teaching that scaffolds deaf students conceptual understanding towards the subject. conceptual understanding towards the different topics covered within prelim, midterm, and final persuasively increases. This is manifested in the scores gained by both genders. Male deaf students garnered mean scores of $37.5,38.5$, and another 38.5 while female deaf students have scores of 38.5 , another 38.5 , and 39.0 respectively which interpreted as High. Furthermore, the statistics indicate the progress of conceptual understanding of deaf students from prelim, midterm, and final. The high scores they have in the post-test is a manifestation that Facebook Messenger assist to develop their conceptual understanding, thus, they got high scores in the given examination. This was further supported by their positive and active interaction with the author/teacher in the online class using Facebook Messenger as an educational platform to scaffold their conceptual understanding in Environmental Science subject as reflected on the transcript of interaction in the Facebook Messenger chat group. 
Table 4

Comparison on male and female deaf students' level of conceptual understanding in Environmental Science subject before (pre-test) and after (post-test) exposure to Facebook Messenger

\begin{tabular}{llllllll}
\hline Variable & $\mathbf{N}=\mathbf{4}$ & Mean & Std. Dev. & $\boldsymbol{d f}$ & $\boldsymbol{t}$-ratio & $\boldsymbol{p}$-value & Interpretation \\
\hline Prelim & Male (Pre) & 9.50 & 4.95 & 1 & -.143 & 0.91 & Not Significant \\
\hline & Female (Pre) & 10.0 & & & & & \\
\hline & Male (Post) & 37.5 & 4.243 & 1 & -.333 & 0.80 & Not Significant \\
\hline Midterm & Female (Post) & 38.5 & & & & & \\
\hline & Male (Pre) & 11.0 & 2.12 & 1 & 1.00 & 0.50 & Not Significant \\
\hline & Female (Pre) & 9.50 & & & & & \\
\hline Male (Post) & 38.5 & 2.828 & 1 & .000 & 1.00 & Not Significant \\
\hline & Female (Post) & 38.5 & & & & & \\
\hline & Male (Pre) & 9.00 & 3.54 & 1 & .200 & 0.87 & Not Significant \\
\hline & Female (Pre) & 8.50 & & & & & Not Significant \\
\hline
\end{tabular}

The data establish that there was no significant difference in the level of conceptual understanding of deaf students when they are group according to gender as to pre-test and post-test. That means regardless of male or female they have the same level of conceptual understanding in the different term examination administered before and after the intervention program was implemented. This was supported by the t-ratio of -.143 for prelim, 1.00 for the midterm, and .200 for the final at the $p$-value of $0.91,0.50$, and 0.87 for the male and female in the pre-test and $-.333, .000$, and -.143 at the $p$-value of $0.80,1.00$, and 0.91 in the post-test respectively. The obtained probability value is greater than 0.05 level of significance; thus, the hypothesis implied by the author that there is no significant difference in the level of deaf students' conceptual understanding in Environmental Science subject in the pre-test and post-test between gender groups is thereby Accepted.

Table 5

Difference on deaf students' level of conceptual understanding in Environmental Science subject before (pre-test) and after (post-test) exposure to Facebook Messenger among gender

\begin{tabular}{llllllll}
\hline Variable & $\mathbf{N}=\mathbf{4}$ & Mean & Std. Dev. & $\boldsymbol{d f}$ & $\boldsymbol{t}$-ratio & $\boldsymbol{p}$-value & Interpretation \\
\hline Prelim & Male (Pre) & 9.50 & 1.41 & 1 & -28.0 & 0.02 & Significant \\
\hline & Male (Post) & 37.5 & & & & & \\
\hline & Female (Pre) & 10.0 & 2.12 & 1 & -19.0 & 0.03 & Significant \\
\hline Midterm & Female (Post) & 38.5 & & & & & \\
\hline & Male (Pre) & 11.0 & 2.12 & 1 & -18.3 & 0.04 & Significant \\
\hline & Male (Post) & 38.5 & & & & & \\
\hline & Female (Pre) & 9.50 & 2.83 & 1 & -14.5 & 0.04 & Significant \\
\hline Final & Female (Post) & 38.5 & & & & & \\
\hline & Male (Pre) & 9.00 & .707 & 1 & -59.0 & 0.01 & Significant \\
\hline & Male (Post) & 38.5 & & & & & \\
\hline & Female (Pre) & 8.50 & .707 & 1 & -61.0 & 0.01 & Significant \\
\hline
\end{tabular}

Table 5 suggests that the pre-test and post-test results are significant among gender. This means that there is a positive difference in terms of the scores gained by male deaf students from pre-test to post-test similar to the female deaf students. It simply shows that deaf students' conceptual understanding of the Environmental Science subject was improved after Facebook Messenger was employed by the author/teacher as a teaching tool to scaffold their understanding of the subject. This was supported by their gained $t$-ratio of $-28.0(p$-value 0.02$),-18.3(p$ value 0.04$)$, and -59.0 ( $p$-value 0.01$)$ for male in the pre-test and post-test from prelim, midterm and final respectively. On the other hand, the female pre-test and post-test yielded the t-ratio of -19.0 ( $p$-value 0.03$)$ for the prelim, -14.5 ( $p$-value 0.04) midterm, and -61.0 ( $p$ value 0.01 ) for the final interpreted as Significant. The obtained probability value is less than 0.05 level of significance; thus, the hypothesis implied by the author that there is no significant difference in the level of deaf students' conceptual understanding in Environmental Science subject in the pre-test and post-test among gender is thereby rejected. 
Table 6

Difference on pre-test and post-test gain scores as to the effectiveness of Facebook Messenger as an educational platform to scaffold deaf students' conceptual understanding in Environmental Science subject

\begin{tabular}{|c|c|c|c|c|c|c|c|}
\hline Variable & $\mathrm{N}=4$ & Mean & Std. Dev. & $d f$ & t-ratio & p-value & Interpretation \\
\hline \multirow[t]{2}{*}{ Prelim } & Pretest & 9.75 & 1.50 & 3 & -37.7 & 0.00 & \multirow[t]{2}{*}{ Highly Significant } \\
\hline & Posttest & 38.0 & & & & & \\
\hline \multirow[t]{2}{*}{ Midterm } & Pretest & 10.3 & 2.22 & 3 & -25.5 & 0.00 & \multirow[t]{2}{*}{ Highly Significant } \\
\hline & Posttest & 38.5 & & & & & \\
\hline \multirow[t]{2}{*}{ Final } & Pretest & 8.75 & .82 & 3 & -73.5 & 0.00 & \multirow[t]{2}{*}{ Highly Significant } \\
\hline & Posttest & 38.8 & & & & & \\
\hline
\end{tabular}

The given statistical data manifest the strong points and the positive effect of Facebook Messenger as an educational platform in scaffolding deaf students' conceptual understanding of Environmental Science subject. Notably, the data revealed that the scores of deaf students in the post-test with the given 50 items multiple-choice examination for prelim, midterm, and final gained an increasing scale respectively. Moreover, it can be concluded based on the findings that the given figures are congruent to the inference of the author that deaf students develop the mastery and understanding the concepts in Environmental Science subject the moment they were exposed to Facebook Messenger as an intervention in the experiment to scaffold their conceptual competence towards the subject. The overall $0.00 p$-value strongly highlights the findings of the experiment as highly significant. Thus, since the derived $p$-value is less than the standard level of significance, which is 0.05 , thus, the author's hypothesis that there is no significant difference in the level of conceptual understanding of deaf students in the pre-test and post-test is thereby rejected.

\section{DISCUSSION}

The 21st century brings transformational breakthroughs in different aspects of life, specifically in education. The world is now adopting the new educational system called inclusive education wherein students with special needs are mainstreamed in the regular learning environment that adheres to the ideals, aspirations, and principles of UNESCO (2017) that "every learner matters and matters equally". However, students with special needs access to quality education in mainstream school remains a challenge worldwide. Slee (2011) suggested that to achieve sustainable, quality, and effective inclusive education there must be a holistic approach in catering to the learning needs of diverse students. The author as a teacher by profession who is handling/teaching deaf students who are considered to be students with special needs designed and modified instruction through the aid of Facebook Messenger as the educational platform to scaffold deaf students' conceptual understanding in Environmental Science subject to enhance and develop deeper comprehension to the different concepts of the subject.

The significant increase in the scores gained by deaf students after the intervention is a clear manifestation of the effectiveness of Facebook Messenger that can enhance their conceptual understanding of different scientific concepts/knowledge they encountered in the teaching process. This was supported by Olusola and Rotimi (2012) stating that if teachers provide students with special needs engaging instructional materials for science classes it can result in positive outcomes in the academic performance of students with special needs. Moreover, Stewart et al. (2012) emphasized instructional materials is important as it creates active interaction to teachers and students with special needs in the teaching-learning process. As attested by the findings, Facebook Messenger can be used by the teachers as an instructional tool to help deaf students with the challenges they encountered in the conventional teaching environment where verbal communication or spoken words is the medium of instruction. The Facebook Messenger chat group approach used by the author/teacher provides an advantage to deaf students since they have difficulty hearing words. If they are not auditory learners, the author believes that they are still the visual type of students where Facebook Messenger has features to offer like written text and videos (with captions) which is advantageous to them for easy communication with the normal students/peers or to their teachers. In fact, according to Lihua and Jiacheng (2010), deaf students preferred text-based instead of verbal modes of communication. They are more prone to use text-based communication with the use of social media like Facebook Messenger (Maiorana-Basas \& Pagliaro, 2014). The high-tech age offers technologies to address barriers in the education process which is adaptive to diverse types of individuals that include deaf students (Zaraii et al., 2011). It is now at the tip of the teacher's finger on how to become creative and innovative to maximize these technologies to make it a productive tool to deliver meaningful learning experiences and quality education to students with special needs. Accordingly, Blom et al. (2014) stressed that to improve the performance of students with special needs teachers may consider the different features of technology as an educational platform in teaching.

In conventional teaching, the author/teacher observed certain behavior of deaf students. They are passive in the classroom discussions and even did not interact with the normal students or with their peers. It was inferred that this may be due to their difficulty communicating as they cannot be grasped and misunderstood by their peers and teachers. Interestingly, the identified behavior noted by the author/teacher shifted into a very active student's 
participation in the actual online class through Facebook Messenger as they are always on time which implied their interest and eagerness to learn the subject. They manifested positive interaction as they respond immediately to the virtual class and shared their insights, ideas, and even clarified concepts that they cannot understand as reflected in the transcript of the Facebook Messenger chat group created exclusively and purposively by the author/teacher for the deaf students. The findings were strengthened by Chen (2014) and Casagrande (2013) that Facebook increases student's motivation and in a similar manner develop their reading and writing skills. However, aside from the quantitative significant findings in the study, there are also qualitative interesting results revealed in the experiment. Notably, it was found out that deaf students cannot understand the local dialect/language (Hiligaynon) the reason why the author/teacher used the English language as the medium of teaching for the whole online class. However, they have difficulty expressing their insights and ideas in the topics of environmental science concepts being discussed. This was analyzed by the author/teacher that this may be due to the influence of American Sign Language (ASL) used by deaf students and their competence in the English language and grammatical errors.

There are responses in the transcript of the Facebook Messenger chat group which the author/teacher cannot grasp and sometimes misunderstood deaf students responses during the online class discussion of the environmental science concepts. Moreover, they revealed that they felt shy with their English language and grammatical errors that deepen the low self-esteem that hinders them to express confidently their thoughts and ideas. The author/teacher spent more than three (3) hours explaining comprehensively with the use of simple words/terms for them to easily grasp the concepts in the Environmental Science subject. The significant findings of the present study negate several studies, for instance, Lau (2017) found out that using social media for academic purposes is not a significant predictor of academic performance as measured by the cumulative grade point average; whilst Elliot et al. (2013) stressed no significant improvement in the Grade Point Average (GPA) and retention of deaf students who use social media for STEM courses. However, the current study underscored that social media like Facebook Messenger has a positive impact on deaf students' academic performance. It enhances their conceptual understanding of the Environmental Science subject manifested on deaf students' high scores gained in the given examination after they were exposed to Facebook Messenger as educational platform utilized by the author/teacher in teaching.

Teaching deaf students is challenging as it requires effort, creativity, and sensitivity to deliver quality and meaningful learning. It becomes more challenging if the teacher cannot do and interpret sign language to deliberately communicate with deaf students. However, the teacher should religiously perform the responsibility as they take allegiance to their profession to educate learners with their maximum capacity to cater to different learning needs adaptable and accessible to diverse students that include students with special needs like the deaf.

\section{CONCLUSION AND RECOMMENDATION}

Education is not a privilege it is a human rights. Every individual deserves to be educated and should have equal access to quality education. The academic institution is expected to accept all types of students including the deaf as they mainstream in an inclusive educational system.

Teaching is regarded as a noble profession. The nobleness of this profession lies in the hands of teachers who continuously pass on the torch that lights the path of success for students. In the teaching process, teachers should ensure to deliver quality and meaningful learning to diverse students that include students with special needs like the deaf. Teacher's good teaching style coupled with interactive instructional tools adaptive to the learning needs of deaf students' foster holistic development and inspire them to aspire to tertiary/college or higher learning in an inclusive learning environment. The practice of inclusive education is no longer limited to special education centers alone but to general/regular classroom as well where students with special needs like the deaf learn side by side with the normal students or peers. The demand of the present time challenges the role of teachers to educate almost fifty (50) normal students and expected to cater for students with special needs in response to the changes of the Philippines' educational system into an inclusive education where students with special needs are mainstreamed in the regular classroom. This entails strong educational support and reasonable accommodation to students with special needs in the context of general education.

The advent of technology holds promise in different aspects of life specifically in the education arena. It becomes indispensable in the life of deaf students as it serves as an ally to interact in the mainstream society and the academe with the normal students or peers. Certain developed technologies had been proven effective to assist deaf students and these become their virtual teacher that provides skills necessary for survival in the mainstream classes. The essential attribute of technology where social media like Facebook Messenger which provides greater opportunity for teachers to become creative and innovative to maximize its unique feature as an educational tool in the teaching-learning process especially in teaching deaf students. The author/teacher suggest and recommend Facebook Messenger as it was a proven effective educational platform that scaffolds deaf students' conceptual understanding and enhances their academic performance in Environmental Science subject. This simply shows the prominence of technology in the education process that assist students with special needs to learn and teachers to become responsive in the challenges they play in educating deaf students. 
Facebook Messenger is widely used by deaf students as an essential tool to express their minds, feelings, and communication, especially to acquire learning. It offers a clear vision for teachers to modify functional and differentiated special education instruction to develop deaf students holistically.

The current study purely focuses on the metaanalysis of the effectiveness of Facebook Messenger and no other contexts investigated. There are certain limitations that the study has not underscored such as it only utilized a few numbers of deaf students in the experiment. Results were solely dependent on the scores provided by the single group composed of four participants in the given examination without any other intervening variables for comparison. Thus, the future direction of the study may delve deeper as to the effectiveness of Facebook Messenger to scaffold conceptual understanding to other disciplines employing a greater number of deaf participants. Moreover, researchers may consider replicating the current quasi-experimental research utilizing two groups for comparison to further validate the result.

\section{REFERENCES}

Alborz, A., Slee, R. \& Miles, S. (2013). Establishing the foundations for an inclusive education system in Iraq: Reflection on findings from a nationwide survey. International Journal of Inclusive Education, 17(9), 965-987.

Antoniadis, I., Koukoulis, I. \& Serdaris, P. (2017). Social networking sites' usage in a period of crisis. A segmentation analysis of Greek college students. In: A. Kavoura, D. P. Sakas, and P. Tomaras, eds. Strategic innovative marketing: 4th IC-SIM, Mykonos, Greece 2015 (pp. 73-79). Springer International Publishing. 10.1007/978-331933865-1 9.

Atekyereza, P. R. (2001). The education of girls and women in Uganda. Journal of Social Development in Africa, 16(2), 115-146.

Aydin, S. (2012). A review of research on Facebook as an educational environment. Educational Technology Research and Development, 60(6), 1093-1106.

Barnes, C. \& Sheldon, A. (2010). Disability, politics and poverty in a majority world context. Disability \& Society, 25(7), 771-782.

Blom, H., Marschark, M., Verloed, M. P. J. \& Knoors, H. (2014). Finding friends online: Online activities by deaf students and their well-being. PLOSONE, 9(2), e88351.DOI:10.1371/journal.pone.0088351

Casagrande, V. (2013). Learning languages in social networks: deaf people's perception of facebook as a linguistic environment. (PhD Thesis), Ca' Foscari University of Venice. http://hdl.handle.net/10579/4561

Chakuchichi, D., Nyaruwata, L. \& Chataika, T. (2015). Leonard Cheshire Disability (LCD): Promoting inclusive primary education in Mashonaland West Province, Zimbabwe-An End of Evaluation Report. Leonard Cheshire Zimbabwe Trust (Lenard Cheshire Disability International).

CHED (2000). CHED Memorandum Order (CMO) $23 \mathrm{~s}$ 2000. Quality education for learners with special needs. https://ched.gov.ph/cmo-23-s-2000/
Chen, Y. T. (2014). A study to explore the effects of selfregulated learning environment for hearingimpaired students. Journal of Computer Assisted Learning, 30(2), 97-109.DOI:10. 1111/jcal.12023.

Chowdhry, A. (2017, Aug 14). SnapChat vs. Facebook from a first mover to a fast follower standpoint." Forbes.

https://www.forbes.com/sites/amitchowdhry/2017 /08/14/snapchat-vs-facebook-from-a-first-moverand-fast-follower-standpoint/?sh=795c5b543f8b

Cologon, K. (2013). Inclusion in education: towards equality for students with disability. Children with Disability Australia.

Constine, J. (2017, Apr 13). Facebook Messenger hits 1.2 billion monthly users, up from $1 \mathrm{~B}$ in July. TechCrunch

Constine, J., Lomas, N. \& Biggs, J. (2016). "Facebook 'Messenger Day' is the chat's app's new SnapChat Stories clone." TechCrunch. https://techcrunch.com/2017/04/12/messenger/? ncid=rss

D'Alessio, S. (2011). Inclusive education in Italy. A critical analysis of the policy of Integrazione Scolastica. Sense Publishers.

Dabbagh, N. \& Kitsantas, A. (2012). Personal learning environment, social media, and self-regulated learning: a natural formula for connecting formal and informal learning. The Internet and Higher Education, 15(1), 8.DOI:10.1016/j.ineduc.2011.06.002.

Dela Fuente, J. A. (2021). Implementing inclusive education in the Philippines: College teacher experiences with deaf students. Issues in Educational Research, 31(1), 94110.http://www.iier.org.au/iier31/dela-fuente.pdf

Deloitte Access Economics (2017). Review of education for students with disability in Queensland state schools. Department of Education and Training. Retrieved from http://education.qld.gov.au/schools/disability/docs /disability-review-report.pdf.

Elliot, L. B., Rubin, B., DeCaro, J., \& Clymer, E. W. (2013). Creating a virtual academic community for STEM students. Journal of Applied Research in Higher Education, 5(2), 173188.DOI:10.1108/JARHE-11-2012-0051.

Ellsworth, N. J. \& Zhang, C. (2007). Progress and challenges in China's special education development: Observations, reflections, and recommendations. Remedial and Special Education, 28(1), 5864.DOI:10.1177/07419325070280010601.

Greenhow, C., \& Askari, E. (2017). Learning and teaching with social network sites: a decade of research in $\mathrm{K}-12$ related education. Education and Information Technologies, 22(2), 623645.DOI:10.1007/s10639-015-9446-9.

Lau, W. W. F. (2017). Effects of social media usage and social media multitasking on the academic performance of university students. Computers in Human Behavior, 68, 286291.DOI:10.1016/j.chb.2016.11.043.

Lihua, S., \& Jiacheng, X. (2010). Using social software to improve learning performance of deaf university learner. Proceedings of 2nd IEEE International Conference on Information Management and 
Engineering (pp. 703-706). IEEE. 10.1109/ICIME.2010.5478205.

Maiorana-Basas, M., \& Pagliaro, C.M. (2014). Technology use among adults who are deaf and hard of hearing: a national survey. Journal of Deaf Studies and Deaf Education, 19(3), 400410.DOI:10.1093/deafed/enu005.

Male, C., \& Wodon, Q. (2017). The price of exclusion: Disability \& Education. Disability gaps in educational attainment and literacy. The World Bank.

http://documents.worldbank.org/curated/en/3962 91511988894028/pdf/121762-replacement-

PUBLICWorldBank-GapsInEdAttainmentLiteracyBrief-v6.pdf

Muderedzi, J., \& Ingstad, B. (2011). Disability and social suffering in Zimbabwe. In A.H. Eide \& B. Ingstad (Eds). Disability and Poverty: A Global Challenge. Policy Press.

Myers, J., Pinnock, H., \& Suresh, S. (2016). Costing Equity: The case for disability-responsive education financing. IDDC Inclusive Education Task Team.

NCDA. (2013). National Council on Disability Affairs guidelines in the admission of students with disabilities in higher education and postsecondary institutions in the Philippines.

OECD. (2012). Equity \& quality in education: Supporting disadvantaged students \& schools. OECD Publishing

Olusola, O., \& Rotimi, C. (2012). Attitudes of students towards the study of physics in college education Ikere Ekiti, Ekiti Sate, Nigeria. American International Journal of Contemporary Research, 2(12), 86-90.

Porter, G., \& Towell, D. (2013). Advancing inclusive education. Keys to transformational change in public education systems. Federicton, Inclusive Education Canada, and London, Centre for Inclusive Futures.

PSA. (2010). Philippines statistics authority. https://psa.gov.ph

Raike, A. (2011). Potter meets popper: how to collaborate for better deaf education? In Partners in education: Issues and Trends from the 21st International Congress on the Education of the Deaf, Vol. 9781563684, (pp.147-158). Gallaudet University Press.

Salkind, N. J. (2010). Encyclopedia of research design. SAGE Publications. DOI:10.413/978141296088.

Saunders, K. C. (2016). Double-edged sword: social Media as a tool of online disinhibition regarding American Sign Language and deaf cultural experience marginalization, and as a tool of cultural and linguistic exposure. Social Media + society, 2(1), 205630511562452.DOI: 10.1177/ 2056305115624529.

Singal, N. (2016). Education of children with disabilities in India and Pakistan: Critical analysis of developments in the last 15 years. Prospects, 46(1), 171-183.

Slee, R. (2011). The irregular school: exclusion, schooling, and inclusive education. Routledge.

Slee, R. (2018). Inclusive education isn't dead, it just smells funny. Routledge.
Statista (2018). Number of Facebook users in the Philippines from 2015 to 2022 (in millions). https://www.statista.com/statistics/490455/numbe r-of-philippines-facebook-users/

Stewart, I., Devon, J., Mckee, W., Harrison, D., \& Allan, M. (2012). Applying the prototyping methodology to develop a student centered, integrated eLearning resource. In $\mathrm{H}$. Beldhuis, ed. Proceedings of the 11Th European conference on E-learning (pp. 541-551). Academic Conferences International Limited.

The World Bank (2008). Kenya Poverty and Inequality Assessment Volume l: Synthesis Report. https://openknowledge.worldbank.org/handle/109 86/3081?show=full

Tomlinson, S. (2017). A sociology of special and inclusive education. Exploring the manufacture of inability. Routledge.

UNESCO (2017). A guide for ensuring inclusion and equity in education. UNESCO. http://unesdoc.unesco.org/images/0024/002482/ 248254e.pdf

UNESCO Institute Statistics UIS (2017). Data for the sustainable development goals. UNESCO.

UNICEF (2018). Child marriage: Latest trends and future prospects. UNICEF.

Vrettaros, J., Argiri, K., Stavrou, P., Hrissagis, K., \& Drigas, A. (2010). Evaluation study of pedagogical methods and $\mathrm{E}$ - learning material via Web 2.0 for hearing impaired people. In M.D. Lytras, ed. Technology enhanced learning: Quality of teaching and educational reform. Springer, 73, 595-601. 10.1007/978-3-642-13166-0_83.

Ward, C. L., \& Seager, J. R. (2010). South African street children: A survey and recommendations for services. Development Southern Africa, 27(1), 85100.

World Health Organization (2011). World Report on Disability. World Health Organization

Yu, L., Su, X., \& Liu, C. (2011). Issues of teacher education and inclusion in China. Prospects, 41, 335-369. 10.1007/s11125-011-9204-8.

Zaraii Zavaraki, E., \& Toofaninejad, E., (2011). The effect of blended learning on student's achievement. In Proceedings of Global Learn Asia Pacific 2011, 1913-1916. https://www.learntechlib.org/p/37422 